\title{
Drivers and Outcomes of Credibility and Parasocial Interaction to Purchase Intentions
}

\author{
Dyah Astarini ${ }^{1}$, Arwini Sumardi ${ }^{2}$ \\ \{diah.astarini@trisakti.ac.id ${ }^{1}$, arwinisumardi11@gmail.com² ${ }^{2}$, \\ Faculty of Business and Economy, Universitas Trisakti ${ }^{1,2}$
}

\begin{abstract}
This research analyzed the effect of physical attractiveness, attitude homophily, social attractiveness, and relationship-building motives on credibility and parasocial interaction, and attitude towards brands and advertisements on purchase intention. Online questionnaires were sent to 200 respondents selected using non-probability and purposive sampling. Hypothesis testing involved Structural Equation Model (SEM) and AMOS Software. Findings showed that physical attractiveness positively affected credibility but had no positive influence on parasocial interaction. Attitude homophily positively affected credibility but had no positive influence on parasocial interaction. Social attractiveness positively affected parasocial interaction. Relationship-building motives positively affected parasocial interaction. Credibility positively affected parasocial interaction and attitudes toward brands and advertisements. However, credibility did not affect purchase intention. Parasocial interaction positively affected purchase intention. Brand attitude had no positive impact on purchase intention. Attitude towards advertisement positively affected purchase intention. We combined two similar studies to determine drivers and outcomes of credibility and parasocial interactions on purchase intentions.
\end{abstract}

Keywords: Physical Attractiveness; Attitude Homophily; Social Attractiveness; Relationship Building Motive; Credibility; Brand Attitude; Parasocial Interaction; Attitude Towards Advertisement; Purchase Intention

\section{Introduction}

Due to the increasing number of new business units, companies must create an effective and unique marketing approach to attract consumers. The Fourth Industrial Revolution or Industry 4.0 and Covid-19 pandemic require the use of the Internet of Things, in the sense that companies use the internet as a marketing medium. The internet provides various conveniences in finding information. Furthermore, the internet expands the company's reach to potential consumers. The following Table 1 shows the total number of Indonesian internet users. 
Table 1. Total Indonesian Internet User in January 2019

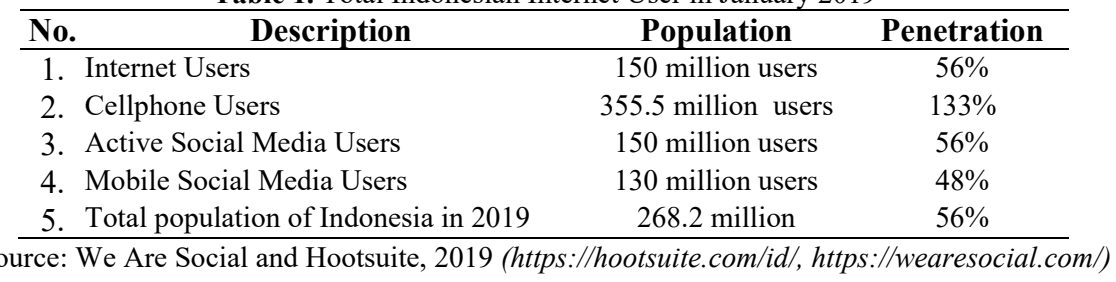

Table 1 illustrates that Indonesia has adapted to the digital era. Mobile phones have $>100 \%$ penetration. Therefore, companies may expand their reach to consumers. Influencer marketing is carried out through various social media platforms, such as Youtube, Instagram, Facebook, Twitter, Line, Snapchat, Blogspot, Tumblr, etc. Table 2 shows the top 100 Youtuber Categories in Indonesia.

Table 2. Top 100 Youtuber Category in Indonesia

\begin{tabular}{ccc}
\hline No. & Content & Percentage \\
\hline 1. & Vlog & $39 \%$ \\
2. & Game & $19 \%$ \\
3. & Music & $14 \%$ \\
4. & Popular Information & $11 \%$ \\
5. & Others & $17 \%$ \\
\hline
\end{tabular}

Source: Social Blade and Tirto.id, 2019 (https://tirto.id/https://socialblade.com/)

Table 2 confirms that video blogs (Vlogs) have the highest public demand. Therefore, the majority of influencers use vlogs as a means for product promotion. According to [1] companies need to find and maintain a good relationship with influencers on social media. Influencers can become opinion leaders. Uploaded content can affect brands and products, as well as influence potential consumers. In general, companies use influencers to increase awareness, educate potential consumers, increase the number of followers, and increase sales capacity $[2,3]$.

[4] proved that influencers possessing high physical attractiveness are considered interesting, credible, have high intelligence, social aptitude, and integrity. Physical attractiveness affects consumer perceptions of influencer credibility [1] Therefore, physical attractiveness affects influencers' credibility. [5] stated that physical attractiveness increased interactions (parasocial interaction). In addition, physical attractiveness increases consumer desire to see influencers [6]. Physical attractiveness increases the engagement (parasocial interaction) between consumers and influencers. The engagement between influencers and consumers is in the form of information exchange and communication through available platforms.

[7] stated that credibility influenced consumers through the internalization process by sharing the values and behaviors homophily perceived by consumers and influencers [1]. The common ground between influencers and consumers affects consumers' perception. The consumer will consider the influencers credible and reliable. Therefore, homophily influences the influencers' credibility. [1] proved that consumers tended to identify themselves (attitude homophily) with the influencers. Consumers create a good relationship (parasocial interaction) with the influencers. In short, consumers identify themselves or have common ground with influencers. Consumers duplicate influencers' behavior, which in turn builds relationships with influencers. Therefore, the homophilic attitude influences parasocial interactions. 
[6] proved that consumers preferred to communicate and develop relationships with people with similar social attractiveness (parasocial interactions) or common ground. The common ground between the consumer and the influencers encourages them to identify themselves with the influencer and create a parasocial relationship. Therefore, social attractiveness influences parasocial interactions. [5] stated that individuals with relationship-building motives paid more attention to the information provided by influencers [4]. Influencers provide various information to consumers through parasocial interactions. Consumers, due to the relationshipbuilding motive, will engage with the information. Therefore, the relationship-building motive influences parasocial interaction.

Furthermore, [8]stated that credibility affected the interaction of feelings between influencers and consumers (parasocial interaction). [6] stated that credibility affected consumer behavior and persuasive messages. Parasocial interaction involves the exchange of information and shapes consumer behavior (desire to buy products). [9] stated that higher influencer credibility increased the purchase intention of the potential customer. An influencer with high credibility and reliability encourages the consumer to believe in the provided information. Therefore, increasing the purchase intention of the consumers. [6] stated that, despite the one-way relationship between consumers and influencers, the influencer might affect customer perception of products and brands. The influencer builds consumer opinion on a product. Therefore, the influencer may increase consumers' purchase intention.

The description above illustrates the crucial role of influencers in social media to increase purchase intention. The novelty of this research was the factors influencing credibility and parasocial interaction. The research also determined the consequences of influencer role in social media on purchase intention. The urgency of this research focused on the importance of marketing promotion through virtual ads using a capable influencer to increase sales volume.

\subsection{Conceptual Framework}

The following Figure 1 describes the conceptual framework of this research:

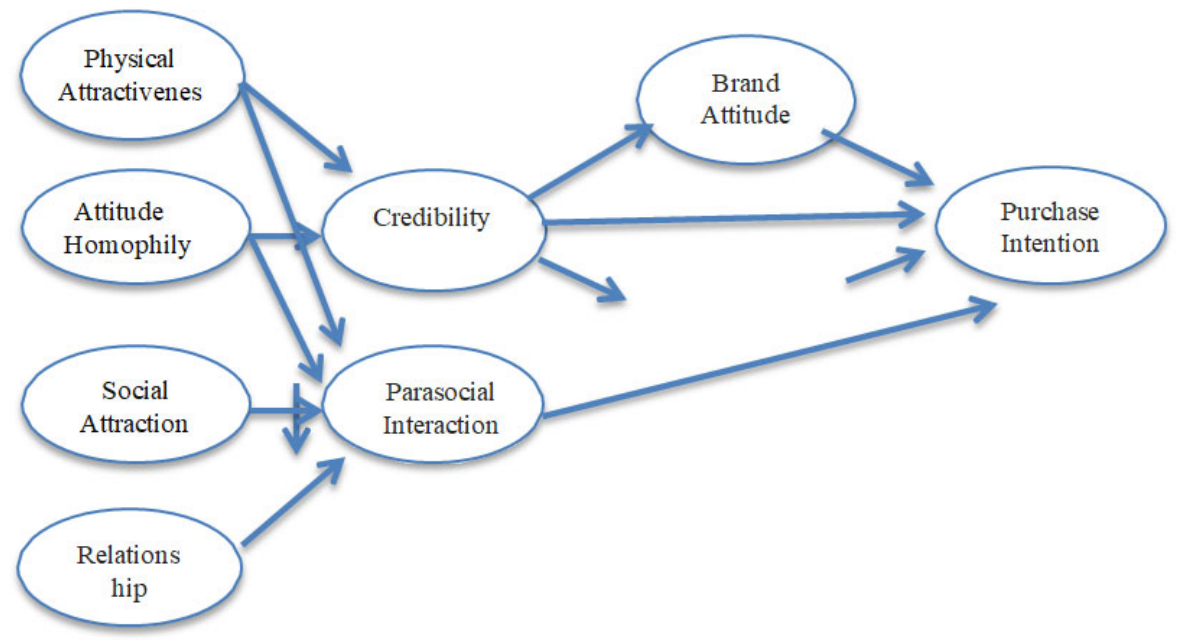

Fig. 1. Conceptual Framework 


\subsection{Hypothesis Development}

Influencer credibility is related to how their facial and physical appearance can be used as sales assessments [1,8]. Physically attractive influencers are considered competent (intelligence and social) and possess high integrity [4]. Physical attractiveness shows competence and trust, which are attributes of credibility (Chaker et al., 2019; Liu et al., 2019). Therefore, influencers with high physical attractiveness increase credibility levels.

H1: Physical attractiveness has a positive influence on credibility

Attraction to influencers increases engagement between influencer and consumer [6]. The engagement frequency and attraction level increase parasocial interaction between influencer and consumer [1]. According to [6] and [4], physical attractiveness may predict parasocial interaction.

$\mathrm{H} 2$ : physical attractiveness has a positive influence on parasocial interactions.

The level of credibility of a blog may positively affect behavior or attitude towards the blog itself [12]. Homophily is the degree used by people who interact based on similar beliefs, education, social status, and preferences [6]. Individuals with the common ground can build trust [1], an attribute of credibility [11]. Therefore, higher attitude homophily between influencers and consumers increases credibility level.

H3: Attitude Homophily has a positive influence on credibility

Individuals who identify themselves with an influencer will increase parasocial interaction [4]. Consumers tend to identify themselves and create a good relationship with the influencer $[1,6]$.

H4: Attitude Homophily has a positive influence on parasocial interactions

Individuals prefer to develop friendly relationships with individuals possessing common ground $[1,6]$ The common ground between consumer and influencer develops parasocial interaction [4,6]. High engagement level through social attractiveness will create parasocial interaction between influencer and consumer.

H5: Social Attractiveness has a positive influence on Parasocial Interactions.

Despite the one-way relationship nature between influencers and consumers, the influencer may influence consumers' perception of products and brands [6]. The need for engagement influenced the relationship between influencers and followers [4]. Individuals possessing relationship-building motives will pay more attention to the information provided by the influencer [4,5].

H6: Relationship-building motive has a positive influence on parasocial interaction

Influencer credibility, media features, and consumer characteristics influence parasocial interaction [13]. According to [8] credibility directly influences parasocial interaction. Consumers tend to think that the influencer has a high level of credibility. Therefore, consumers are interested in maintaining a relationship.

H7: Credibility has a positive influence on parasocial interaction

Attractive influencers may influence individuals through the identification process [1]. Consumers adapt to influencer consumption patterns by consuming influencer-recommended products [14]. According to [15,16] consumers want to identify themselves with influencers. In doing so, the consumers will purchase influencer recommended products. [6] showed that parasocial interaction between consumers and influencers positively affected the perception of a brand. Furthermore, parasocial interaction increases purchase intention [17].

H8: Parasocial interaction has a positive influence on purchase intentions.

Consumers may purchase a product when an influencer is credible and reliable [1]. Influencer credibility affects consumer behavior and purchase intention [8]. [4] stated that 
physically attractive influencers and high credibility encouraged consumers to favor a brand and increase purchase intention. [16] stated that influencers with a high level of credibility could increase purchase intention.

H9: Credibility has a positive influence on purchase intention

[8] proved that credibility might be measured by determining how influencers affect consumers through emotion, attractive image, attention to the customer, influencer capability level, influencer knowledge, influencer marketing capability, and influencer experience. [1] measured credibility through influencer ability, efficiency, trust, consumer care, and content. The factors influence consumer behavior toward a product.

H10: Credibility has a positive influence on brand attitude

One creative method to promote a product through available media is to utilize influencers. Influencers may create a positive attitude. Influencers need to provide information and leave a deep impression of the brand and product attributes. Then, influencers need to be responsible, pleasant, and convincing. In doing so, an influencer may affect consumer psychology easily [18].

H11: Credibility has a positive influence on attitude towards advertisement

Attitude toward brands is a positive attitude of a consumer to a brand. It influences purchase intention. Influencers may influence consumer behavior by recommending products or brands [19]. Influencers build brands in consumer's minds. In doing so, influencers affect purchase intention. Therefore, attitude toward brands increases purchase intention.

H12: Attitude Toward Brand has a positive influence on purchase intentions

Advertising is the core of the marketing mix to increase sales [19]. Previous research shows that advertising effectively influences consumer behavior and increased purchase intention. Marketers tend to use celebrity endorsement to provide clear and interesting product information. Using celebrity in endorsement attracts consumer and increase purchase intention [20].

H13: Attitude toward advertisement has a positive influence on purchase intentions

\section{Research Method}

The research design used hypothesis testing. Sample collection used a non-probability sampling method. This research used a cross-sectional dimension, a study conducted in a period to determine the real environmental condition [21]. We used an individual analysis unit. Data were collected employing a google-form online questionnaire. The total respondents were 200 individuals filing out a 30-item questionnaire. We adopted the items from [1], which consisted of physical attractiveness (2 items), attitude homophily (2 items), social attractiveness ( 2 items), relationship building motives (6 items), credibility (5 items), and parasocial interactions ( 2 items). We also adopted items from [19], which consisted of brand attitude (4 items), advertisement attitude ( 5 items), dan purchase intentions ( 2 items). This research used purposive sampling and the following criteria: 1) respondents had watched influencers' video blogs of cosmetics, health, food/beverages, and travel; and 2) respondents had watched a minimum of three different products video blogs for the last month. The questionnaire items used a Likert Scale (1-5) with five alternatives ( 1 = strongly disagree; 2 = disagree; 3 = slightly agree; 4 = agree; 5 = strongly agree).

We used the validity test and reliability test to assess instruments. The variables are valid when the validity test produced a loading factor $>0.40$ [22] The variables are valid when the reliability test produced Cronbach's Alpha $\geq 0.6$ [22] 


\section{Findings and Discussion}

The total respondents were 200 individuals, and the majority were female (146 women or $73 \%$ ). The respondent age was between $18 \geq 41$ years old, and the majority were $24-34$ years old $(61.5 \%)$. As many as 112 respondents had bachelor's degrees (56\%), and 74 respondents were private company employees (37\%). The majority of the respondents $(31.5 \%)$ earned IDR 9,000,000.- per month. Then, $66(33 \%)$ respondents watched food vlogs, and $60(30 \%)$ respondents watched beauty-related vlogs. The majority of respondents used Instagram $(52.5 \%)$ and Youtube (45\%). In addition, 159 (79.5\%) respondents purchased influencerrecommended products. Table 3 presents the result of the validity and reliability test. Table 4 presents the Goodness of Fit test result.

Table 3. Validity and Reliability Test Result

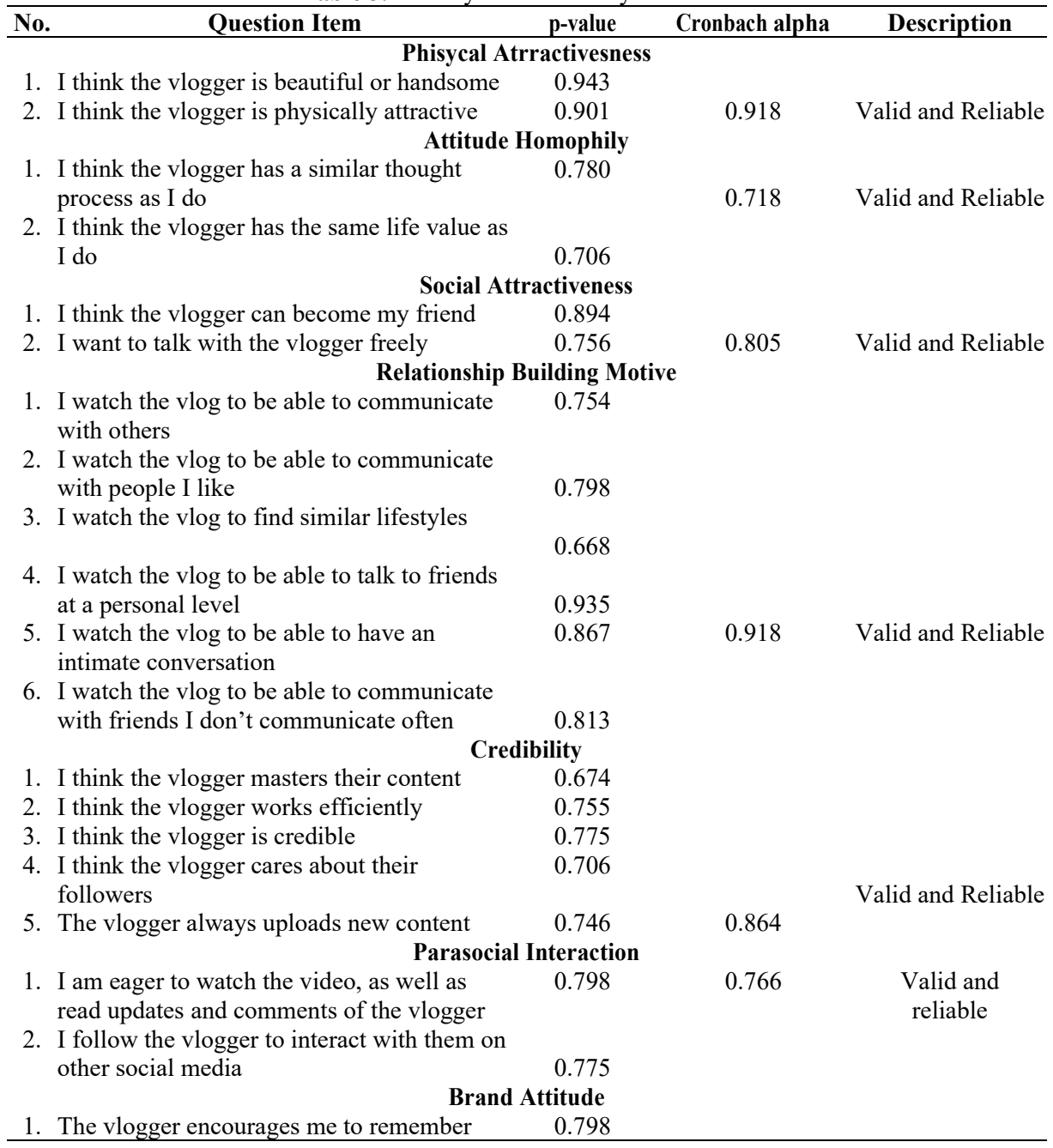




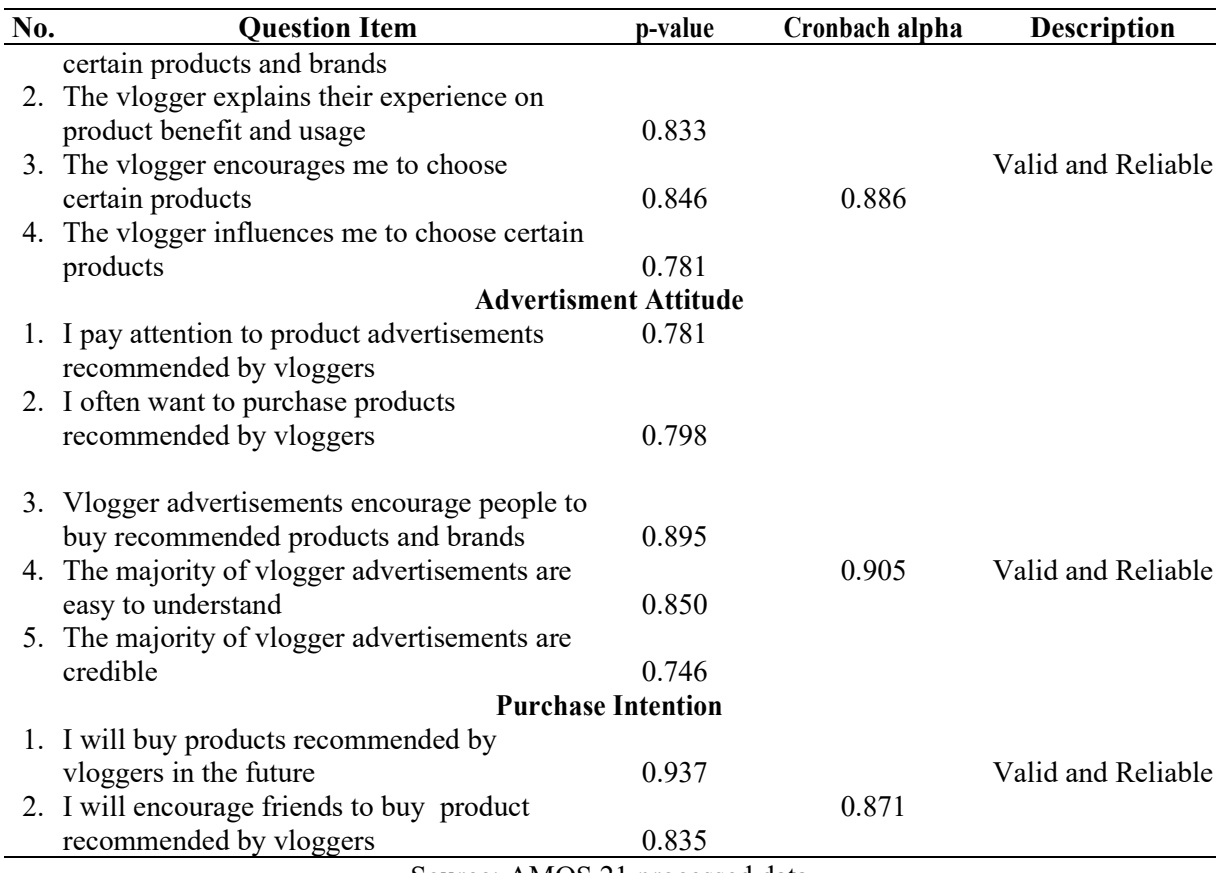

Source: AMOS 21 processed data

Table 4. The Goodness of Fit Test Result

\begin{tabular}{lcccc}
\hline Measurement Type & Measurement & Cut Off & Value & Description \\
\hline \multirow{3}{*}{ Absolute Fit Indices } & Sig. Probability & $\geq 0.05$ & 0.000 & Poor Fit \\
& GFI & $\geq 0.90$ & 0.757 & Poor Fit \\
& RMSEA & $\leq 0.10$ & 0.085 & Goodness of Fit \\
& NFI & $\geq 0.90$ & 0.800 & Marginal Fit \\
Incremental Fit Indices & TLI & $\geq 0.90$ & 0.853 & Marginal Fit \\
& CFI & $\geq 0.90$ & 0.870 & Marginal Fit \\
& RFI & $\geq 0.90$ & 0.774 & Poor Fit \\
Parsimony Fit Indices & IFI & $\geq 0.90$ & 0.871 & Marginal Fit \\
& AGFI & $\leq$ GFI & 0.707 & Goodness of Fit \\
\hline
\end{tabular}

Source: AMOS 21 processed data (attached)

Tabel 5. Descriptive Statistics

\begin{tabular}{lcc}
\hline \multicolumn{1}{c}{ Variable } & $\begin{array}{c}\text { Mean } \\
\text { Standard Deviation }\end{array}$ \\
\hline Physical Attractiveness & 3.773 & 0.940 \\
Attitude Homophily & 3.588 & 0.851 \\
Social Attractiveness & 3.518 & 1.008 \\
Relationship Building Motive & 3.072 & 1.027 \\
Credibility & 4.319 & 0.627 \\
Parasocial Interaction & 3.660 & 0.936 \\
Brand Attitude & 3.920 & 0.851 \\
Attitude towards Advertisement & 3.669 & 0.843 \\
Purchase Intention & 3.513 & 0.940 \\
\hline \multicolumn{2}{c}{ Source: AMOS 21 processed data }
\end{tabular}

Source: AMOS 21 processed data 
Table 5 confirms that physical attractiveness has a mean of 3.773 . The majority of respondents said that influencers had an attractive physical appearance. The majority of respondents viewed influencers as attractive, beautiful, and handsome. Attitude homophily had a mean of 3.588. The majority of respondents stated that influencers have similar thoughts processes and lifestyles. Social attractiveness had a mean of 3.518. The majority of respondents stated that they could be friends and freely talk with the influencer. Relationshipbuilding motives had a mean of 3.072. The majority of respondents stated that watching vlogs helped them communicate, talk to other people, understand their lifestyles, and be close friends. Credibility had a mean of 4.319 .

The majority of respondents stated that the influencers mastered their content, worked efficiently, was credible, and roused interest and care for their followers. Parasocial interaction had a mean of 3.660. The majority of respondents were willing to read the comments of the influencers and interact through various other social media. Brand attitude had a mean of 3.920. The presence of influencers encouraged respondents to remember the product brand, understand its benefits and use, and encourage respondents to choose a particular brand. Attitude towards advertisement had a mean value of 3.669. Respondents paid attention to advertisements easily. The influencers' advertisements helped respondents to purchase products. Then, respondents believe in influencers' recommended products. Purchase intentions had a mean value of 3.513. Respondents would buy products in the future and communicate to their closest friends to buy advertised products. The following Table 6 shows the result of the hypothesis testing.

Table 6. Result of Hypothesis Test

\begin{tabular}{lccc}
\hline \multicolumn{1}{c}{ Hypothesis } & Estimate & p-value & Results \\
\hline H1: Physical Attractiveness $\rightarrow$ Credibility & 0.147 & 0.002 & accepted \\
H2: Physical Attractiveness $\rightarrow$ Parasocial Interaction & -0.008 & 0.454 & rejected \\
H3: Attitude Homophily $\rightarrow$ Credibility & 0.252 & 0.000 & accepted \\
H4: Attitude Homophily $\rightarrow$ Parasocial Interaction & -0.093 & 0.303 & rejected \\
H5: Social Attractiveness $\rightarrow$ Parasocial Interaction & 0.286 & 0.011 & accepted \\
H6: Relationship Building Motives $\rightarrow$ Parasocial Interaction & 0.289 & 0.000 & accepted \\
H7: Credibility $\rightarrow$ Parasocial Interaction & 0.841 & 0.000 & accepted \\
H8: Parasocial Interaction $\rightarrow$ Purchase Intention & 0.253 & 0.004 & accepted \\
H9: Credibility $\rightarrow$ Purchase Intention & 0.000 & 0.500 & rejected \\
H10: Credibility $\rightarrow$ Brand Attitude & 0.996 & 0.000 & accepted \\
H11:Credibility $\rightarrow$ Advertisement Attitude & 0.934 & 0.000 & accepted \\
H12: Attitude toward Brand $\rightarrow$ Purchase Intention & 0.058 & 0.263 & rejected \\
H13: Attitude toward Advertisement $\rightarrow$ Purchase Intention & 0.762 & 0.000 & accepted \\
\hline
\end{tabular}

Source: AMOS 21 processed data

The hypothesis testing showed mixed results. Out of 13 hypotheses proposed, nine were accepted, and four were rejected. Hypothesis 1 assessed the positive effect of physical attractiveness on credibility. The estimated coefficient value was 0.147 and p-value was 0.002 $<0.05$. Ho was rejected, and Ha was accepted. Therefore, physical attractiveness had a significant positive effect on credibility. Physical attractiveness is associated with positive characters, being beautiful or handsome, and attractive physical appearance. $[6,13]$ stated that one of the main forms of attractiveness was appearance, namely the first impression others received in an interaction.

Hypothesis 2 assessed the positive effect of physical attractiveness on parasocial 
interaction. The estimated coefficient value was -0.008 , and the p-value was $0.454>0.05$. The research finding showed that physical attractiveness did not have a positive effect on parasocial interaction. Respondents were not willing to watch videos, read uploaded posts, and write comments. However, respondents interacted with influencers in various media. [1] stated that consumers were willing to engage with influencer videos, posts, and comments. Consumers follow and interact with influencers on other social media.

Hypothesis 3 assessed the positive effect of attitude homophily on credibility. The estimated coefficient value was 0.252 , and the p-value was $0.000<0.05$. Ho was rejected, and Ha was accepted. Therefore, attitude homophily had a significant positive effect on credibility. Attitude homophily means that consumers have similar thought processes and lifestyles as the influencers. Consumers develop a homophilic attitude when they have common ground with influencers.[6] and [1] supported our findings.

Hypothesis 4 assessed the positive effect of attitude homophily on parasocial interaction. The estimated coefficient value was -0.093 , and the p-value was 0.303 . Therefore, attitude homophily did not have a positive effect on parasocial interaction.[23] and [1] did not support our findings. Previous research defined parasocial interaction as the process and result of the connection between the mass media users and the relationship development with various types of human representation in various media.

Hypothesis 5 assessed the positive effect of social attractiveness on parasocial interaction. The estimated coefficient value was 0.286 , and the p-value was $0.011<0.05$. Ho was rejected, and $\mathrm{Ha}$ was accepted. Therefore, social attractiveness had a significant positive effect on parasocial interaction. Respondent considers influencers as a friend they can talk to. [1] and [24] supported our findings. Previous research mentions that social attractiveness is the probability of becoming friends or choosing a figure as a co-worker in a media.

Hypothesis 6 assessed the positive effect of credibility on parasocial interaction. The estimated coefficient value was 0.289 , and the p-value was $0.000<0.05$. Ho was rejected, and Ha was accepted. Therefore, the relationship-building motive has a significant positive effect on parasocial interaction. Respondents used relationship-building motives to communicate, talk, and understand the influencers' lifestyles. In addition, respondents watch vlogs to being able to talk privately and intimately to influencers. [4] stated that individuals having relationship-building motives with influencers would pay more attention to the information provided.

Hypothesis 7 assessed the positive effect of credibility on parasocial interaction. The estimated coefficient value was 0.841 , and the p-value was $0.000<0.05$. Ho was rejected, and Ha was accepted. Therefore, credibility had a significant positive effect on parasocial interaction. Respondents understand that vloggers master their content, work efficiently, are trustworthy, inspire new content, and care about their followers. [25] and [1] stated that consumers bought a product advertised by an influencer because they thought the influencer was reliable and trustworthy.

Hypothesis 8 assessed the positive effect of parasocial interaction on purchase intention. The estimated coefficient value was 0.253 , and the p-value was $0.004<0.05$. Ho was rejected, and Ha was accepted. Therefore, parasocial interaction had a significant positive effect on purchase intention. Respondents were eager to watch vlogs because they wanted to read posts and leave comments. [1] stated that consumers bought products advertised by influencers. Consumers wait for influencers' content and want to know product-related information.

Hypothesis 9 assessed the positive effect of credibility on purchase intention. The estimated coefficient value was 0.000 and the p-value was $0.500>0.05$. Ho was accepted, and Ha was rejected. Therefore, credibility had no positive effect on purchase intention. [25] and 
[1] did not support the result of this research. Previous research stated that consumers bought products recommended by influencers due to the influencers' credibility and reliability. [9] stated that higher influencers' review credibility and potential online consumers would increase purchase intentions.

Hypothesis 10 assessed the positive effect of credibility on brand attitude. The estimated coefficient value was 0.996 . It indicated that higher credibility increased brand attitude and vice versa. The p-value was $0.000<0.05$, indicating that Ho was rejected and $\mathrm{Ha}$ was accepted. Therefore, credibility had a significant positive effect on brand attitude. Brand attitude is a comprehensive consumer evaluation of a particular brand and forms the basis used by consumers to determine decisions and behavior towards products and brands [12].[1] supported our findings.

Hypothesis 11 assessed the positive effect of credibility on attitude toward advertisements. The estimated coefficient value was 0.934 , indicating that higher credibility increased attitude toward advertisements and vice versa. The p-value was $0.000<0.05$, indicating that Ho was rejected and Ha was accepted. Therefore, credibility had a significant positive effect on attitude toward advertisements. Respondents paid attention to the vlogger advertisements. The respondents believed in vlogger recommendations and wanted to buy advertised products.

Hypothesis 12 assessed the positive effect of brand attitude on purchase intention. The estimated coefficient value was 0.058 , indicating that increasing credibility would slightly increase purchase intention and vice versa. The p-value was $0.263>0.05$, indicating that Ho was accepted and Ha was rejected. Therefore brand attitude did not affect purchase intention. The result of this research was not supported by [12] stating that brand attitude refers to consumers' thorough evaluation of a brand, which forms consumer decision and behavior.

Hypothesis 13 assessed the positive effect of attitude toward advertisements on purchase intention. The estimated coefficient value was 0.762 , and the p-value was $0.000<0.05$. Ho was rejected, and Ha was accepted. Therefore, attitude toward advertisements has a significant positive effect on Purchase Intention. Respondents paid attention to influencers' product advertisements. Respondents understood the advertisement and were willing to buy the advertised product. They considered that the influencers used easy-to-understand advertisements and delivered trustworthy information. This research was supported by [26].

\section{Conclusion}

The research result showed that physical attractiveness had a positive impact on credibility but had no positive impact on parasocial interaction. Attitude homophily had a positive impact on credibility but had no positive impact on parasocial interaction. Social attractiveness has a positive impact on parasocial interaction. Relationship-building motives had a positive impact on parasocial interaction. Credibility had a positive impact on parasocial interaction, brand attitude, and attitude towards advertisement but had no impact on purchase intention. Parasocial interaction had a positive impact on purchase intention. Brand attitude had no positive impact on purchase intention. Attitude towards advertisement had a positive impact on purchase intention.

The managerial implication of this research is that companies may use influencers to speed up vlog impressions. Consumers can immediately read posts and provide comments on products advertised. In addition, it is necessary to determine general thought patterns and community lifestyles. Therefore, there are no gaps related to mindset and lifestyle. The limitation of this study is that the research area was limited to the Jabodetabek (Jakarta, Bogor, 
Depok, Tangerang, and Bekasi) region and used the existing variables. Future research may expand the research area and add new variables. Future research may also add mediating or moderating variables to produce more comprehensive research.

\section{References}

[1] Sokolova K, Kefi H. Instagram and YouTube bloggers promote it, why should I buy? How credibility and parasocial interaction influence purchase intentions. J Retail Consum Serv. 2020;

[2] Sugiharto SA, Ramadhana MR, Psi S, Psi M. PENGARUH KREDIBILITAS INFLUENCER TERHADAP SIKAP PADA MEREK (Studi pada Mahasiswa Fakultas Komunikasi dan Bisnis Universitas Telkom). J Ilmu Polit dan Komun. 2018;

[3] Mowen JC, Brown SW. On Explaining and Predicting the Effectiveness of Celebrity Endorsers. Advances in Consumer Research. 1981.

[4] Liu MT, Liu Y, Zhang LL. Vlog and brand evaluations: the influence of parasocial interaction. Asia Pacific J Mark Logist. 2019;

[5] Rubin AM, Step MM. Impact of motivation, attraction, and parasocial interaction on talk radio listening. J Broadcast Electron Media. 2000;

[6] Lee JE, Watkins B. YouTube vloggers' influence on consumer luxury brand perceptions and intentions. J Bus Res. 2016;

[7] Kelman HC. Compliance, identification, and internalization three processes of attitude change. J Conflict Resolut. 1958;

[8] Lou C, Yuan S. Influencer Marketing: How Message Value and Credibility Affect Consumer Trust of Branded Content on Social Media. J Interact Advert. 2019;

[9] Kudeshia C, Kumar A. Social eWOM: does it affect the brand attitude and purchase intention of brands? Manag Res Rev. 2017;

[10] Surawski MK, Ossoff EP. The effects of physical and vocal attractiveness on impression formation of politicians. Curr Psychol. 2006;

[11] Chaker NN, Walker D, Nowlin EL, Anaza NA. When and how does sales manager physical attractiveness impact credibility: A test of two competing hypotheses. J Bus Res. 2019;

[12] Colton DA. Antecedents of consumer attitudes' toward corporate blogs: An International Journal. J Res Interact Mark. 2018;

[13] Lee SA, Lee M. Effects of relationship types on customers' parasocial interactions: Promoting relationship marketing in social media. J Hosp Tour Technol. 2017;

[14] Shan Y, Chen KJ, Lin JS. When social media influencers endorse brands: the effects of self-influencer congruence, parasocial identification, and perceived endorser motive. Int J Advert. 2020;

[15] Sohn JW, Kim JK. Factors that influence purchase intentions in social commerce. Technol Soc. 2020;

[16] Kim DY, Kim HY. Influencer advertising on social media: The multiple inference model on influencer-product congruence and sponsorship disclosure. J Bus Res. 2021;

[17] Hwang K, Zhang Q. Influence of parasocial relationship between digital celebrities and their followers on followers' purchase and electronic word-of-mouth intentions, and persuasion knowledge. Comput Human Behav. 2018;

[18] Sebayang MK, Siahaan SDO. Pengaruh Celebrity Endorser Terhadap Keputusan Pembelian Sepeda Motor Merek Yamaha Mio Pada Mio Automatik Club (MAC) 
Medan. Manaj Bisnis. 2008;

[19] Singh RP, Banerjee N. Exploring the influence of celebrity credibility on brand attitude, advertisement attitude and purchase intention. Glob Bus Rev. 2018;

[20] Wang JS, Cheng YF, Chu YL. Effect of celebrity endorsements on consumer purchase intentions: Advertising effect and advertising appeal as mediators. Hum Factors Ergon Manuf. 2013;

[21] Sekaran U, Bougie R. Research Methods For Business. A Skill Builing Approch. 7th Edition. Book. 2018;

[22] Hair JF, Anderson RE, Tatham RL, Black WC. Multivariate Data Analysis, Multivariate Data Analysis. Multivariate Data Analysis, Multivariate Data Analysis B2 - Multivariate Data Analysis, Multivariate Data Analysis. 2018.

[23] Ding Y, Qiu L. The impact of celebrity-following activities on endorsement effectiveness on microblogging platforms: A parasocial interaction perspective. Nankai Bus Rev Int. 2017;

[24] Fernández Gallardo L, Weiss B. Perceived Interpersonal Speaker Attributes and their Acoustic Features. In: Proceedings P\&P13. 2018.

[25] Wathen CN, Burkell J. Believe it or not: Factors influencing credibility on the Web. J Am Soc Inf Sci Technol. 2002;

[26] Chen C-C, Hsiao K-L, Wu S-J. Purchase intention in social commerce. Libr Hi Tech. 2018; 